\title{
EXPERIENCING TELETANDEM: A COLLABORATIVE PROJECT TO ENCOURAGE STUDENTS IN TANDEM INTERACTIONS
}

\author{
Experienciando teletandem: um projeto colaborativo para \\ encorajar interações em tandem
}

Viviane KLEN-ALVES 1

Fernanda Franco TIRABOSCHI ${ }^{2}$

\begin{abstract}
In this paper, we present findings of a semester long collaboration between two instructors: one from a Brazilian high school and the other from an American technical college. We investigated the potential of online in-tandem interactions for the enhancement of students' second language learning. Using Action Research, we assessed the impact of the partnership and our students' participation in two student-guided telecollaborative sessions. In this empirical qualitative study, we conducted semi-structured interviews and distributed a questionnaire to explore our students' attitudes towards language learning and their perceived development of their fluency in the second language. The results encourage partnerships in the format of inter-institutional collaborations to promote students' involvement in communicative tasks in Portuguese and in English. It also demonstrates how this type of telecollaborative activity promotes positive attitudes that indicate the nurturing of students' participation and intercultural competence.
\end{abstract}

Keywords | Telecollaboration. Teletandem. Second language learning. Education. English. Portuguese. Action research.
Resumo | Neste artigo, apresentamos as descobertas de um semestre de colaboração entre duas professoras, uma de uma escola secundária brasileira e a outra de um colégio técnico americano. Juntas investigamos $\mathrm{o}$ potencial das interações em tandem para o aprimoramento da aprendizagem de segunda língua. Partindo de uma perspectiva de pesquisa-ação, avaliamos o impacto da parceria de Teletandem na participação de nossos alunos em duas sessões de telecolaboração conduzidas por eles com nosso apoio. Nessa pesquisa empírica de cunho qualitativo, conduzimos entrevistas semiestruturadas com os alunos e também distribuímos um questionário com o objetivo de explorar as atitudes dos estudantes em relação à própria aprendizagem de línguas e sua percepção de seu desenvolvimento linguístico (aumento da fluência) na segunda língua. Os resultados encorajam parcerias no formato de colaborações interinstitucionais com o objetivo de promover o envolvimento dos alunos em tarefas comunicativas em português e em inglês. Os resultados também demonstram como esse tipo de atividade telecolaborativa promove atitudes positivas que resultam no incentivo ao crescimento da participação estudantil e no aumento da competência intercultural por parte dos alunos.

Palavras-chave | Telecolaboração. Teletandem. Aprendizagem de segunda língua. Educação. Inglês. Português. Pesquisa-ação.

1 Klen-Alves. UGA. E-mail: viviane@uga.edu. ORCID ID: https://orcid.org/0000-0001-7601-9259

2 Tiraboschi. UFG. E-mail: nandafranco87@yahoo.com.br. ORCID ID: https://orcid.org/0000-0002-38127918 
- | Experiencing teletandem: a collaborative project to encourage students' in tandem interactions

\section{Introduction}

There is an increasing motivation to expose students to a second and third language; it exists not only in the US and Brazil, but it also extends worldwide. The demand is that students learn how to speak the language to engage in conversations "in a clearly participatory manner in order to communicate information on autobiographical topics, as well as topics of community, national, or international interest" (ACTFL PROFICIENCY GUIDELINES, 2012) as established in the targets created by The American Council on the Teaching of Foreign Languages for the advanced levels of proficiency.

In our profession as public high school and private technical college educators, we have witnessed a lack of support from administrators and stakeholders in relation to foreign language teaching. In Brazil, the British Council (2015) conducted a survey in 2015 to understand the status of English teaching in Brazilian public schools. After interviewing 1,269 teachers from every region of Brazil, they shared that in terms of technological support, only $26 \%$ of the classrooms have one computer or notebook and only $24 \%$ of them have some internet access. There were more rooms with TVs (31\%), however less than half $(47 \%)$ of the interviewed teachers claim to use any technological resources to teach. In many schools, the computers were broken, waiting for repairs or locked down because of the possibility of burglary. In the US and Brazil, higher education, especially in technical colleges, is seen as an investment. In many cases, study or achieve fluency in a foreign language is not a requirement (INSIDE HIGHER ED, 2017). In both contexts, the foreign language is offered later in the students' academic life and is seen as a secondary subject. Still, we face a number of demands to provide our students with opportunities to access authentic information in the target language and to speak to fluent speakers of the language they are learning. These requests happen even when we do not have access to basic technology as demonstrated on the American Council survey and witnessed in our daily lives. Taking this into consideration, we can ascertain that Brazilian high schools and American technical colleges run the risk of perpetuating major monolingual settings in which the foreign language is never highlighted. The lack of investment in terms of resources and teacher education may affect students' opportunities to be in contact with a new culture, making it difficult for them to achieve advanced levels of proficiency.

To provide students with innovative activities in regular second language programs, language educators are turning to inter-institutional collaborations using Computer Mediated Communication (CMC) to facilitate the contact between their students and speakers of the languages they are learning. CMC is broadly defined as the way in which telecommunication technologies have combined information technology and computer 
networks to offer new tools that support teaching and learning (WARSCHAUER, 1997 apud TOLOSA; ORDÓÑEZ; GUEVARA, 2017). CMC projects have become increasingly popular in the past two decades, but most of the existing research has focused on post-secondary contexts (s.f. O'DOWD; WARE, 2009).

The experience reported here aims to advance the field of in-tandem collaboration by sharing the lessons learned from an experience of telecollaboration between the Brazilian high school students and the American technical college students. The data collected through semi-structured interviews, questionnaires and observations, in addition to the project narration complements the findings previously documented by one of the authors (see TIRABOSCHI, 2017) and are used to demonstrate how the use of CMC can promote students' interaction with the target language and, consequently, support positive attitudes, intercultural competence, and linguistic gains.

\section{Theoretical Background}

As educators, one of our goals was to stay true to the pedagogical practices and curricula principles from both the Brazilian and the American educational systems. The Brazilian standards promote an education that stimulates the cognitive, social and emotional dimension of the human being, so that the contemporary learner is capable of acting and interacting in diverse social practices (BRASIL, 2006). To achieve this goal learners must be able to deal with the recent changes in the multicultural practices of globalization and in the multimodal languages provided by technological advances. In American curricula, the expectation for 'World Language learners' is not different. The American Council on the Teaching of Foreign Language (ACTFL) Performance Guidelines for K-12 and the Georgia Performance Standards for Modern Languages state that foreign language teaching should equip students with lifelong skills that will enable them to function competently in a language other than their own (s.p). In addition, learners should be able to communicate and compete effectively in the global community and marketplace. In this context, learning the new language is to raise awareness of one's own and other cultures, increasing students' cultural repertoire and appreciation for other languages ${ }^{3}$, in addition to preparing students for a more diverse world and job market.

3 Modern Languages and Latin. (n.d.). Retrieved from https://www.georgiastandards.org/standards/pages/ BrowseStandards/ModernLanguageLatin.aspx 
- | Experiencing teletandem: a collaborative project to encourage students' in tandem interactions

\section{Principles and concepts of Telecollaboration via Teletandem}

Considering the overarching curricula presented above, we used Teletandem to connect these language learners in synchronous CMC activities. Teletandem ${ }^{4}$ (TELLES; VASSALLO, 2006) was chosen because the two instructors were familiar with it. The Teletandem project is the precursor of this modality of CMC in Brazil. It counts among its participants several professors and researchers from State University of São Paulo - UNESP (campuses Araraquara, Assis and São José do Rio Preto) and allows university students from different countries to interact with each other from their home institution computers in order to teach their languages and learn the languages of their peers (CAVALARI; ARANHA, 2016).

Teletandem, as a CMC platform, promotes meaningful communicative engagement, increased motivation and enhanced practice of the target language (TELLES; VASSALLO, 2006, CAVALARI; ARANHA, 2016). Tandem learning can be understood as an "intercultural and knowledge exchange of ideas between individuals from different cultures with a collaborative language learning objective." ${ }^{\prime \prime}$ (BENEDETTI; CONSOLO; ABRAHÃO, 2010, p. 21). Accordingly, Teletandem follows the model of tandem learning with the addition of digital resources (Skype, Facebook, Oovoo, etc.) that allows for synchronous or asynchronous interaction in the oral (listening and speaking), writing (reading and writing) and image forms (TELLES; VASSALLO, 2006).

Teletandem is also commonly associated with the term "telecollaboration" which, in turn, refers to collaborative learning in a virtual context (TELLES, 2015; FIGUEIREDO; SILVA, 2015; BELZ, 2002). Collaborative learning (WARSCHAUER, 1997) is based on the principles of sociocultural theory, which argues that learning and development take place through the mediated interaction between humans (VYGOTSKY, 1962). Under this sociocultural perspective, we define collaborative learning as a situation in which learners engage in the interaction, collaborating with each other to carry out a given task (FIGUEIREDO, 2006, DONATO; MCCORMICK, 1994, LANTOLF; APPEL, 1994). The interactions via Teletandem have three fundamental principles of tandem learning: language separation, reciprocity and autonomy (CAVALARI; ARANHA, 2016; TELLES, 2015; TELLES; VASSALLO, 2006).

The first principle, language separation, has to do with the need to divide the time of interaction via Teletandem into two parts, each part being reserved for the practice of a language. The second, reciprocity, refers to the language and culture role during 4 Also known as "Teletandem Brazil: Foreign Languages for All” (see TELLES; VASSALLO, 2006).

5 No original "intercâmbio e compartilhamento de conhecimento entre indivíduos de culturas diferentes, com propósitos de aprendizagem de línguas de modo colaborativo." (BENEDETTI, 2010, p. 21). 
the interaction. During the interactions, each learner should assume either the learner role of the target language, or the role of specialist in his or her language of proficiency, not undermining each other's languages and cultures. The third, autonomy, refers to the student's independence in Teletandem. "[Students] are autonomous in their learning, but they can resort to a teacher's professional mediation [during the interactions] if they wish" (SALOMÃO, 2015, p.784). In the integrated format of Teletandem, students are in charge of some of the decisions regarding their learning and the route they take during the interaction. They are responsible for negotiating with their interlocutors (language peers) the ways in which they can help one another achieve their own goals during the period of participation in the interactions.

The development of a more autonomous learning, in the context of Teletandem, does not dispense with the participation and intervention of the teachers in the classroom. The autonomy is negotiated in the relationship between educators and students, and students with their peers. According to Little (1991) "autonomy is not self-instruction or learning without a teacher, it does not involve the banning of the teacher's interventions and support in the learning process." ["a autonomia não é auto instrução ou aprendizagem sem professor, não envolve o banimento das intervenções ou iniciativas do professor no processo de aprendizagem"] (LITTLE, 1991 apud MOURA FILHO, 2009, p. 258). Thus, as instructors, we are responsible for the learning environment, creation of tasks for our students, acting as mediators during the sessions, and observing how they participate in the Teletandem activity without our aid.

We agree with Dickinson (1994) when he argues that it may take time for students to develop language learning autonomy. Therefore, researchers-teachers should collaborate with the students in order to guide them through the use of strategies that encourage the progressive development of their autonomy in their collaborative action and production of knowledge with their peers. For this reason, we have to make sure students understand the tasks involved with participating in the Teletandem sessions and provide them with tools to support their learning.

In recent years, Teletandem has grown to become its own in-tandem modality. During the II International Meeting on Foreign Language Learning in Tandem, different institutions around the globe went to Miami to share how they have adopted and adapted Teletandem concepts to develop political, educational and pedagogical platforms of their own. Figueiredo and Silva (2015) present, in their article, experiences of Brazilian apprentices from the Federal Institute of Goiás (Campus de Goiânia) and German apprentices from two institutions in Germany with telecollaborative interactions from the open-meetings application. The inter-institutional project "Teletandem UEPB" promotes 
- | Experiencing teletandem: a collaborative project to encourage students' in tandem interactions

collaborative and linguistic exchange activities in Portuguese and Spanish between the State University of Paraíba (Campus of Monteiro and Campina Grande), Federal University of Pernambuco (Caruaru campus), Federal Institute of Paraíba (Monteiro campus), Federal Institute of Latin American Integration and the Institute of Languages of Salta (Argentina) (LINS; SOUZA, 2016).

In the same conference, Hasko, Moser and Klen-Alves presented a paper on Enhancing Oral Proficiency via Telecollaboration in LCTL classrooms: The case of L2 Portuguese. In addition to demonstrating how international sites are adopting Teletandem, they discussed the need for more empirical studies on fluency in Teletandem and the importance of studying and assessing students' oral proficiency development before, during, and after the Teletandem experience. Inspired by the different takes on Teletandem and more specifically by Teletandem Institucional Integrado (iiTTD) as presented by Cavalari and Aranha (2016). For this partnership, we have adopted a form of iiTTD in our collaboration between the high school and the technical college students. To date, Teletandem practices are part of the teaching and learning routines of many universities; however, it is still new in most public and technical schools around the world. In the context of Basic Education in Brazilian public schools, the use of Teletandem is an innovative pedagogical action. Nonetheless, it faces multiple challenges, since most of these schools do not have the basic conditions for an effective Teletandem practice; for example, they lack an equipped computer lab. In the North American context, sometimes there is a false belief that technology would not be an issue. In other words, because the technical college is situated in North America, some people believe that it has the necessary financial resources and technology for in-tandem interactions. However, in our experience it was the opposite. In addition to all the bureaucracy related to inter-institutional collaborations, we were not able to reserve a computer lab for Teletandem interactions. Consequently, in order to open the frontiers of intercultural communication and give our students the opportunity to develop their linguistic and intercultural skills, we had to adapt Teletandem to our teaching situations and classroom limitations.

\section{Contexts of the research}

\section{Context I}

Six high school students from the Brazilian school of integral education located in the interior of Goiás participated in this research. The students, aged from 15 to 18 , participated in the interactions as part of an extracurricular class (elective course) named "English for Fun". The purpose of the course was to sensitize learners to the influence of 
English cultural aspects through communicative interactions. The goal was to stimulate their critical intercultural awareness of the English language through games, play, and various digital tools.

\section{Context II}

Also participating in this study were five out of the seven technical college students studying Portuguese 2 at a technical college located in the southeastern United States. These students aged between 16 and 20. The Portuguese 2 course was a continuation of the Portuguese 1 course; it aimed to familiarize students with the language and culture of Portuguese-speaking countries and to help them achieve basic Brazilian Portuguese proficiency. To achieve this goal, the course was focused on basic principles of grammar, pronunciation, reading and writing through the communicative method. It requires the active participation of students through dramatizations, dialogues and question-andanswer exercises.

\section{Focal Participants}

The project involved a total of eleven students aged between 15 and 20, and their respective Portuguese and English teachers. These students were beginning learners of the language and, with the exception of one American student, had never travelled abroad.

In the Portuguese class, five of the seven students chose to participate in the interactions, while two students chose not to participate and worked on a one-to-one guided project instead. These students mentioned a lack of confidence in speaking in the target language as the main reason for not participating in the project. That was a valid reason, as the students had only been exposed to Portuguese for one semester (18 weeks) when they first heard about Teletandem and were invited to participate in the pilot project.

In the Brazilian public high school, all students enrolled in the discipline "English for fun" chose to participate in Teletandem. At first, we noticed that although some of them felt somewhat anxious about their language skills, after preparing for the interactions and participating in them, they all felt the experience was positive. It is worth noting that the project, approved by both institutions, was voluntary and did not require students to participate in the activities without their consent. At the end, only data from the eleven participants who consented to participate and complete the activity were used. 
- | Experiencing teletandem: a collaborative project to encourage students' in tandem interactions

\section{Methodology}

This study follows the qualitative research paradigm. According to Bortoni-Ricardo (2008), the qualitative paradigm allows the teachers to associate their daily pedagogical practice with the research exercise.

This article aimed to explore students' attitudes towards language learning and their perceived development of their fluency in the second language via CMC. In order to achieve this goal, we combined the analysis of our observation journals, semi-structured interviews, questionnaires, and interactions analysis. The analysis of these data allows us to answer the following questions:

1. What were our students' prior experiences with $\mathrm{CMC}$ ?

2. Have they ever used CMC to communicate with people of other countries/ cultures?

3. Before the Teletandem experience, have they used the internet or any other digital resources to learn the target language?

In addition to these three questions, after the interactions, the students who participated in this study were invited to talk about their experience and to complete the research questionnaire. During the semi-structured interviews, students were requested to talk about the two Teletandem sessions with the overseas program and to tell us whether or not they enjoyed the sessions and why. The data collected were then coded and only accessed by the two teachers participating in this project. The research findings can be seen below.

\section{The Teletandem experience between the Brazilian school and the American college}

The experience reported in this article started when we found out that we both had interest in Teletandem and were doing research on it.

We officially started our collaboration in the middle of January of 2017. We talked about our classes and negotiated the possibility of facilitating sessions of Teletandem with our students. At first, we wanted to hold Teletandem sessions during the semester, but we later narrowed the window down to the months of March and April. Unfortunately, we encountered numerous limitations in the planning of these sessions. Some of these 
limitations included the differences between the start and end dates of the semester, the difference in time zone, the lack of resources such as computers with individual headset and camera for each student, and the already planned curricular activities which afforded little flexibility to change. Resisting these initial limitations, we insisted on maintaining the project as a pilot experience. After agreeing on a calendar and common goals, we guided the eleven participating students in the Teletandem principles of separation of languages, reciprocity, and autonomy.

During the first part of the semester (January and February), the students and we investigated the technologies available on our respective campuses to decide on the tools that we would use. We compared the dates in relation to the content prescribed for the semester and negotiated the active participation of our students in the preparation for the sessions and in the sessions per se. We constantly engaged our students in this project by suggesting that they should create personal goals for the interactions and prepare questions according to their needs and curiosities about the other cultures. We, as teachers-researchers, interacted several times through email, Facebook, and WhatsApp to discuss the development of what had been planned and the next steps prior to the interactions.

Initially and ideally, the sessions were going to be individual (each student using one computer to communicate with another student), but this was not possible because the Brazilian school had a limitation on available computers and no access to a computer lab. We also wanted to hold multiple sessions from the outset, but after investigating our prescribed calendars, we decided that two sessions would be more feasible. We confirmed the two dates for the interactions and decided to use our own classrooms spaces for the two one-hour sessions.

We tested WhatsApp desktop, Skype, and Facebook Messenger video call several times before the interactions to assess which of those applications would work best. After the tests, we decided to use Skype, and, if necessary, Facebook Messenger would be our backup app. Each teacher reserved a notebook, a projector, and a speaker and sound box to create a video conference ambience during the interactions. After taking care of the technical issues, we moved on to the students' profiles. We shared information about the students with each other in an effort to pair them during the interactions. The pairing of students consisted of observing their age (15-20), proficiency in English and Portuguese (consistently similar), and noticeable likes and dislikes to somehow create a match and avoid the situations where one student dominates the interaction, respecting the principles of separation of languages and reciprocity. Corroborating to this mission, we decided in collaboration that the first session was going to be guided by the Portuguese students. The 
- | Experiencing teletandem: a collaborative project to encourage students' in tandem interactions

English students were responsible for the second session. Following these principles, in the first session students started speaking English for 30 minutes and then Portuguese for 30 minutes, but in the second session they started with Portuguese and then moved to English (CAVALARI; ARANHA, 2016).

\section{The two interactions between the students}

Prior to the first interaction, the teachers and students collaboratively elaborated a list with 19 questions in Portuguese and English. This list was based on the lexical and grammatical elements that had already been taught by both teachers in the classroom. The list included simple basic questions that students could use to get to know one another, in addition to questions about likes and dislikes and everyday life. Students also added questions related to the study routines, customs, tastes, and ways of acting to the list.

During the first session, the students sat in a semicircle which facilitated the interaction between the students since they could see each other clearly. The interaction began with the use of the Skype video call. We asked the students to introduce themselves one by one. We then wrote their names in the chat box, so students could continue to look at each other's names during the session. The students then went through the 19 questions, but to balance out the number of turns between the two groups we decided that one group would ask ten questions while the other group would ask the remaining nine. The Portuguese students began the process by asking questions in Portuguese and directing them to people who would be their peers. The English students answered the questions and also asked follow-up questions in Portuguese so that the Portuguese students would take an active turn and answer questions in the target language. After the first 30 minutes, we asked students to rotate. At that moment, English students started asking questions, but now in English while the Portuguese students started responding to the questions and asking follow-up questions when needed. If we hadn't stopped the session after one hour, students would have continued to speak with each other. They asked several questions beyond what was proposed in the 19-question list. They were so engaged in the conversation that they forgot the peer assignment and started asking other students questions. It was common to hear students asking what everyone else did or thought about something. The students asked additional questions about personal preferences, tourist spots in Brazil and the US, customs, hobbies, and study routines.

During the interaction, students relied on each other and on the teacher-researchers for help whenever they needed to reformulate or create a new question, or to make sure they were being understood by their interlocutors. They also sought to help each other 
by politely repeating a word to emphasize pronunciation or by explaining expressions or words. Sometimes, students or teachers repeated sentences used by their overseas peers with the correct grammatical and lexical structures to help them notice the mistakes, or they simply answered the questions while making corrections in a polite way.

For the second interaction, the Brazilian students proposed a conversation about popular musical styles in Brazil and the United States. Unfortunately, the call dropped twice during this phase. The teachers communicated via WhatsApp and decided to switch to Facebook messenger. Still, the connection was quite poor, which made students and teachers alike feel somewhat frustrated. During the session, when we were able to hear each other, the English students asked questions about North American music and its influence around the world. Each student shared what type of music they listen to and the teachers used the opportunity to introduce new vocabulary in both languages. Towards the end, students exchanged contact information and many students from both groups added the teachers and some peers on social media.

As mediators, we introduced the topics of both interactions to students beforehand, trained them on the Teletandem pillars, and supported them during the preparation prior to the interactions. These steps helped alleviate the anxiety about speaking with speakers of the other language and allowed students to have a sense of readiness even though they were still beginner learners of the second language. During the interactions, the idea was that they would practice their autonomy, knowing that they had the teachers to provide them support if they needed. At the end of the sessions, the teachers interviewed the students in order to evaluate and discuss the Teletandem experience.

\section{Findings}

\section{Students' prior experience with CMC}

Only two of the six Brazilian participants answered that they had previous experiences of intercultural interaction with people from other countries through social networks, discussion forums and Skype before participating in Teletandem. In the case of the American students, two of the five participants also reported similar experiences. The first, son of former missionaries in Brazil, would be present when his parents communicate informally with their Brazilian friends. The second, fluent in Spanish and English, was put in contact with a Brazilian student by the Portuguese instructor since she had to enroll in an introductory Portuguese level class even though she had a tremendous linguistic advantage when compared to the other students learning a second language without the knowledge of another Romance language. 
- | Experiencing teletandem: a collaborative project to encourage students' in tandem interactions

Although learning that four out of eleven students had previous experiences with CMC can be exciting at first sight, both teachers-researchers experiences confirm that they are exceptions. When we look at their peers and expand the observation to the general students' population in Brazilian public high schools and American technical colleges, we are familiar with, very few students have opportunities to be familiar with other cultures and very few of them study a language long enough to achieve proficiency to participate in communicative tasks in a second language.

There were specific social historical and cultural conditions that allowed these four students to connect with people from other cultures just as there were socio-cultural conditions that separated the other students from these contexts.

\section{Students' use of CMC to interact with people of other countries/cultures}

When asked if they have used CMC to interact with people from other countries, all the participants reported that they have had previous experiences with language learning using diverse digital resources to communicate with people from other countries and cultures.

The instruments reported by the student included subtitled movies, music, tv series, social networks and online forums. They also reported language-learning platforms such as Duolingo and Rosetta Stone. As teachers-researchers, it was our role to unpack the definition of these instruments with students and to help them understand what each instrument was and how the instrument helped them interact with people of other countries and cultures. At first, the teachers had the impression that students did not have a clear understanding of what $\mathrm{CMC}$ entails. For this reason, they explained to students that computer-mediated-communication was any communication by means of interactive platforms. They purposefully gave only one example to students, the use of email, and asked them to separate the other instruments they used into groups. Students from the technical college decided that instant messaging, social media, and Skype interactions were certainly CMCs. They were not sure about subtitled movies, music, tv series and language-learning platforms without human interaction such as Duolingo. We were excited to see students making distinctions, but more importantly noticing that computer mediated communications can happen from a desktop or a cellphone and that many apps, such as WhatsApp, are a type of CMC. 
Students' use of the internet or any other digital resources to learn the target languages

As students were able to name and separate the type of technology that supported their language learning, they could easily identify the tools they have been using (e.g. movies with subtitles) to practice the second language.

We noticed that the students from the technical college mentioned using Rosetta Stone and Duolingo as the only resources to learn a target language while students from Brazil talked about a greater number of resources, including social media, subtitled movies, music, television series, social networks, and online forums.

\section{Students' overall evaluation of the Teletandem experience}

At the end of the Teletandem sessions, the teachers held a semi-structured interview with their students to talk about their responses to the questionnaire and to hear their general opinion about the experience. In this section, we will present the findings regarding students' perceptions on the effects of the interactions via videoconference, and its link, or lack thereof, to the motivation to learn languages through Teletandem.

Hall (2001, p. 22) emphasizes that "current understandings consider the essence of language to be social action, something that exists in use, in communication". From this perspective, teachers must engage learners in authentic interactions in which they will be able not only to use their linguistic knowledge, but also to negotiate meanings, receive and give feedback and analyze their use of language through the help of their interlocutors. It is interesting to note that one of the Brazilian participants mentions that the Teletandem experience has provided them with the application of the theory (the study of linguistic structures) to practice (interaction using authentic use of the target language). We can find evidence of that in the following excerpt ${ }^{6}$ :

(1) Excerpt 1: The video conference provided us with a unique experience that made it possible for us to put theory into practice. Teletandem could help us master oral comprehension, understand language functions and, most importantly, help us to analyze the elements we should improve to master our English... (Tom Watson)

Similarly, an American participant reflects on the Teletandem experience to share his own sense of progress in the second language:

(2) Excerpt 2: "After the interaction, I saw progress in my Portuguese (however, far from good Portuguese). It reminded me how much I want to learn Portuguese. It also strengthens my belief that I learn languages best when I am actually using them in conversations. However,

6 The names have been changed to protect the privacy of our students. 
- Experiencing teletandem: a collaborative project to encourage students' in tandem interactions

talking to people whose native language is Portuguese showed me just how little Portuguese I know and makes me want to learn more." (Jonny)

Although the level of proficiency of all students was similar and all of them were considered beginners in the language, it is important to look at the North American student reflection on the "little" he knew and how he wanted to learn "more". In contrast, the Brazilian student responded that he saw in Teletandem a way to analyze and to master his English. Thus, the Portuguese student seemed to feel more self-conscious about his linguistic abilities. Nonetheless, the Teletandem experience was positive to both groups of students, considering that even when discussing limitations, students reported they wanted to learn more and to continue studying the language to communicate orally with real people.

Additionally, Figueiredo (2006, p. 24) emphasizes that, in situations of collaborative activities, "students have the opportunity to become more reflexive and more autonomous, since, through the exchange of information and points of view, and regulation by the other, they may become self-regulating ". In this sense, it is relevant to highlight that both Tom Watson and Jonny's excerpts revealed the ability to reflect on and recognize their own weaknesses and the elements they were supposed to improve and master. Those abilities are quite related to the self-monitoring learning strategy which characterizes an autonomous and reflexive attitude towards language learning (DICKINSON, 1994). Therefore, it is possible to assume that this experience promoted the activation of the selfmonitoring strategy which, in turn, contributed to a change in student's attitude towards language learning.

The Teletandem principles of separation of languages, reciprocity, and autonomy were visible during the sessions and observed in students' feedback about the Teletandem activity. It is possible to observe that collective scaffolding, which is closely related to reciprocity, occurred during many moments during the two Teletandem sessions as presented in two excerpts below:

(3) Excerpt 3: During the interaction with North American students, I had an incredible feeling. We could see them trying hard to speak Portuguese, and our English group were also trying to be as clear as possible to facilitate understanding. It was one of the best experiences of my life. (Joseph)

(4) Excerpt 4: The video conference was very entertaining and interesting. Even though the conversation occurred in a short time, it was quite enlightening. The differences between our contexts are really significant. Athens's teens seem to be very different from us. Our listening and speaking skills were really put in check. Both groups had difficulties, but they did not embarrass 
us because some students helped each other when there was a question. And the teachers were also at our side to provide us with assistance. We shared very useful information about our daily life, habits, schedules, and personal preferences. (Maryanne)

Joseph's mentions about how the Brazilian group tried to be clear to facilitate the understanding of the North American students highlights the opportunities created for scaffolding during the Teletandem interaction. To Vygotsky (1998), scaffolding is seen as a support structure that enables an individual to perform a task or achieve a learning goal, which he could not do alone, with the help of an adult or a more competent partner. Maryanne's experience corroborates with this sense that the synchronicity of Teletandem allows for opportunities of collaborative mediated interactions that in turn become scaffolding moments as the peers try to help each other during the interactions. Moreover, knowing that they were not alone while their listening and speaking skills were "put in check" allows them to overcome their anxiety and self-consciousness by being free to request help from their peers or instructors, since in group works the assistance does not necessarily come from a more competent peer; that is, each member can contribute to the execution of a common goal using their specific abilities which can sometimes be complementary. (WRETCH, 1979 apud DONATO; MCCORMICK, 1994).

Finally, we noticed that both groups of learners tried to assume the role of facilitators in the Portuguese/English learning process for the other group.

(5) Excerpt 5: "not only did we get to practice our Portuguese, but we also got to practice their English" (Adele)

Adele's speech reflects the Teletandem principle of reciprocity, which emphasizes the equal value to both languages.

In addition to recognizing the interactive aspect of Teletandem, students demonstrated that they could see a clear connection between what they were learning (or already knew), and the planning Teletandem sessions: "I am a hands-on learner, so actually getting to practice what I learned helped." (Maryanne). Jonny, a student at the technical college, started the conversation by saying that "the interaction with the Brazilian student online in class was a fun experience". This statement helped us notice that even though students were part of a video conference between all the eleven students, the peer-topeer experience was more salient to Johnny.

Another important aspect pointed out by Maryanne in excerpt 6 below has to do with the Teletandem activities as a useful, authentic and motivating tool for learning languages. She also emphasizes that this resource provides second or additional 
- Experiencing teletandem: a collaborative project to encourage students' in tandem interactions

language learners with opportunities to engage in authentic intercultural communication (BENEDETTI; CONSOLO; ABRAHÃO, 2010; TELLES, 2015).

(6) Excerpt 6: Videoconferencing is very useful for learning any language. English Teaching with traditional tools cannot offer the experience of interacting with people who speak the target language, because it is quite different. Thus, for people who do not have the opportunity to study or spent time abroad, it's something really helpful. (Maryanne)

As we can observe in the excerpts above, the Teletandem activity offered several benefits to the language learning. Among these contributions are the following: motivation for language learning; encouraging the use of target language; promotion of sociocultural awareness etc. (LINS; SOUZA, 2016; TELLES, 2015).

\section{Final Considerations}

In this study, we played the role of mediators of the Teletandem activities and, at the same time, reflected on the effects of such activities on the learning of our students. The findings of this research support the continuation of inter-institutional partnerships and suggests that increased motivation to continue learning and using the language can be reached and encouraged via Teletandem even after only two sessions between students. Our findings also confirm that cultural encounters, like the one experienced via Teletandem, can promote student participation and the development of students' intercultural competence. By examining the research data and reflecting on the study we have conducted, new ideas on how we can understand and plan Teletandem sessions have emerged. The recommendations below could serve as the basis for future research involving inter-institutional collaborations, action research, and collaborative research design.

Resources. As we collaborated to make this partnership possible, we noticed that we needed more time to plan and collect resources before implementing the interactions. We have learned that it would be important to formalize the partnership between institutions prior to the academic semester so that we could, for example, invite the administration to have a bigger role in the project and request the available resources beforehand. The entire project was carried out from the context of our regular classrooms, using our own computers. A positive side of it was that we were able to collectively assess the impact of the project on our students' learning and we had the material readily available. A downside was that had we had access to a computer lab with stable internet, cameras and headsets, students would have been able to interact on a one-one basis. 
Sample size. Most of the research on Teletandem thus far has been conducted at the college level. We could not rely on previous studies to complement our data. Taking into consideration that we only had a total of eleven students in our classrooms, we had to limit the scope of our analysis to this small sample. Consequently, our study works as a pilot project as it does not offer a substantially large sample that can be generalized to every high school and technical college experience. In the future, having a larger sample would help us to confirm our observations that in Brazilian public high schools and American technical colleges, very few students have opportunities to be exposed to a foreign language long enough to achieve advanced proficiency. Nonetheless, the experimental character of our Teletandem experience revealed itself to be an opportunity for students to take part in contextualized and meaningful learning opportunities in the foreign language. The results of this research encourage inter-institutional collaboration with the goal of promoting students' involvement in communicative tasks and nurturing their intercultural competence and fluency in the foreign language.

Methodology. As young scholars, we collaborated in the design of the study and each step of the way, including data collection and the discovery of our theoretical and methodological lens. We used Action Research to plan our collaboration and to conduct a rigorous observation of the students' participation in the two Teletandem sessions. For future research, we would like to apply a more robust intake of Action Research to address our participation in the research as researchers and instructors. We would also like to extend the discussion of ways in which we engage our students in each step of the research project. We believe that by expanding our understanding of Action Research, and by revisiting our methods of analysis, we can strengthen this qualitative study and reduce any limitations in our collaborative design.

Finally, as we assess these limitations in relation to the overall findings of our study, we see them as lessons learned as part of the continuous processes of conducting educational research. We believe that our study corroborates with the field of Telecollaboration, or more specifically, to the body of research on Teletandem, and calls attention to new opportunities to encourage the use of Teletandem in high schools and technical colleges, expanding the already existing circle of Teletandem usage. We hope that our study serves as the basis to carry on broader empirical studies, and that many of the outcomes presented here can be achieved by future research in the field. 
- Experiencing teletandem: a collaborative project to encourage students' in tandem interactions

\section{References}

AMERICAN COUNCIL ON THE TEACHING OF FOREIGN LANGUAGES. The ACTFL Proficiency Guidelines 2012 - Speaking. ALEXANDRIA, VA, 2012.

ANDERSON, T. Modes of interaction in distance education: Recent developments and research questions. In: MOORE, M. G.; ANDERSON, W. G. (ed.). Handbook of distance education. London, England: Erlbaum, 2003. p. 129-144.

ARANHA, S.; CAVALARI, S. A trajectorial do Projeto Teletandem Brasil: Da Modalidade Institucional não Integrada à Institucional Integrada. The ESPecialist, São Paulo, v. 35, n. 2, p. 183-201, 2014.

ARANHA, S.; CAVALARI, S. M. S. Institutional Integrated Teletandem: What have we been learning about writing and peer feedback? DELTA - Revista de Estudos Em Linguística Teórica e Aplicada, São Paulo, v. 31, n. 3, p. 763-780, 2015.

ARANHA, S.; TELLES, J. Os gêneros e o Projeto Teletandem Brasil: Relação entre compartilhamento e sucesso interacional. In: VI SIGET - Simpósio Internacional de Estudos de Gêneros Textuais. 6., Natal. Anais... Natal: UFRN, 2011.

BELZ, J. A. Linguistic perspectives on the development of intercultural competence in telecollaboration. Language Learning \& Technology. v. 7, n. 2, p. 68-99, 2003.

BELZ, J. A. Social dimensions of telecollaborative foreign language study. Language Learning \& Technology. v. 6, n. 1, p. 60-81, 2002.

Benedetti, A. M.; CONSOlO, D. A.; ABRAHÃO, M. H. V. Pesquisas em ensino e aprendizagem no Teletandem Brasil: línguas estrangeiras para todos. São Paulo: Pontes, 2010.

BORTONI-RICARDO, S. M. O professor pesquisador: introdução à pesquisa qualitativa. 2. ed. São Paulo: Parábola Editorial, 2008.

BRASIL. Secretaria de Educação Básica. Ministério da Educação. Orientações Curriculares para o Ensino Médio - Linguagens, códigos e suas tecnologias. Brasília, 2006. Available in: http://portal.mec.gov.br/seb/arquivos/. Access: July 152018. 
BRITISH COUNCIL. O ensino de inglês na educação pública brasileira: elaborado com exclusividade para o British Council pelo Instituto de Pesquisas Plano CDE. São Paulo, SP: British Council Brasil, 2015. Available in: https://www.britishcouncil.org.br/sites/default/ files/estudo_oensinodoinglesnaeducacaopublicabrasileira.pdf. Access: Nov. 282018.

CAVALARI, S. M. S.; ARANHA, S. Teletandem: Integrating e-learning into the foreign language classroom. Acta Scientiarum Language and Culture, Paraná, v. 38, n. 4, p. 327336, 2016.

CHUNG, Y. G.; GRAVES, B.; WESCHE, M.; BARFURTH, M. Computer-mediated communication in Korean-English chat rooms: Tandem learning in an international languages program. Canadian Modern Language Review, Toronto, v. 62, n. 1, p. 49-86, 2005.

COPE, B.; KALANTZIS, M. (ed.). Multiliteracies: New literacies, new learning. Pedagogies: an International Journal, Singapore, v. 4, n. 3, p. 164-195, 2009.

COPE, B.; KALANTZIS, M. (ed.). Multiliteracies: Literacy learning and the design of social futures. London: Routledge Press, 2000.

DICKINSON, L. Learner autonomy: what, why and how? In: LEFFA, V. J. (org.). Autonomy in Language Learning. Porto Alegre: UFRGS, 1994.

DONATO, R.; MCCORMICK, D. A sociocultural perspective on language learning strategies: The role of mediation. The modern language journal, v. 78, n. 4, p. 453-464, 1994.

FIGUEIREDO, F. J. Q. de. A aprendizagem colaborativa de línguas: algumas considerações conceituais e terminológicas. In: FIGUEIREDO, F. J. Q. de. (org.). A aprendizagem colaborativa de línguas. Goiânia: Ed. da UFG, 2006. p. 11-45.

FIGUEIREDO, F. J. Q.; SILVA, S. V. Teletandem language learning in a technological context of education: interactions between Brazilian and German students. DELTA, v. 31, n. 3, p. 729-762, 2015.

HALL, J. K. Classroom interaction and language learning. Ilha do Desterro, v. 41, n.1, p. 1739, 2001. 
- | Experiencing teletandem: a collaborative project to encourage students' in tandem interactions

HASKO, V.; MOSER, R.; GUIDA, F.; HAYES, M. E.; KLEN-ALVES, V. Maximizing Oral Proficiency Development via Telecollaborative Partnerships in the Portuguese Flagship Program. In: MURPHY, D.; EVANS-ROMAINE, K. (org.). Exploring the US Language Flagship Program Professional Competence in a Second Language by Graduation. Bristol; Buffalo; Toronto: Multilingual Matters, 2016. p. 90-115.

HELM, F.; GUTH, S. (org.). Telecollaboration 2.0: Language, literacies and Intercultural Learning in the 21stCentury. Bern: PeterLang AG, InternationalerVerlagDerWissenschaften, 2010.

INSIDEHIGHERED.COM. 2018. Undergraduate foreign language requirements aren't particularly effective (essay) | Inside Higher Ed. [online]. Available in: https://www. insidehighered.com/views/2017/05/18/undergraduate-foreign-language-requirementsarent-particularly-effective-essay. Access: 29 Nov. 2018.

LANTOLF, J. P.; APPEL, G. (org.). Vygotskian approaches to second language research. Westport, Connecticut, London: Greenwood Publishing Group., 1994.

LINS, É. F.; SOUZA, F. M. Letramento digital e audiovisual como potencializadores da aprendizagem colaborativa do português e do espanhol como línguas adicionais. EntreLínguas, Araraquara, v. 2, n. 1, p. 51-66, 2016.

LONG, M. H. Focus on form in task-based language teaching. In: LAMBERT, R. D.; SHOHAMY, E. G. (org.). Language Policy and Pedagogy: Essays in Honor of A. Ronald Walton. Philadelphia; Amsterdam: John Benjamins Publishing Company, 2000. p. 179-192.

LONG, M. H. Focus on form Theory, research, and practice. In: LONG, M. H.; ROBINSON, P. (ed.). Focus on form in classroom second language acquisition, v. 15, p. 15-41, 1998.

LUZ, E. B. P. Variáveis influenciadoras da continuidade ou descontinuidade de parcerias de teletandem à luz da teoria da atividade. 2012. Tese (Doutorado) - Instituto de Biociências, Letras e Ciências Exatas, Universidade Estadual Paulista, São José do Rio Preto, 2012.

MALONE, M.; RIFKIN, B.; CHRISTIAN, D.; JOHNSON, D. E. Attaining high levels of proficiency: Challenges for language education in the United States. Journal for Distinguished Language Studies, v. 2, p. 67-88, 2004. 
MOURA FILHO, A. C. L. O que há em um nome? O estado-da-arte da autonomia na aprendizagem de línguas. Revista Linguagem \& Ensino, v. 12, n. 1, p. 253-283, 2012.

O'DOWD, R.; WARE, P. Critical issues in telecollaborative task design. Computer-Assisted Language Learning, v. 22, n. 2, p.173-188, 2009.

PARK, Y. Understanding synchronous computer-mediated classroom discussion through cultural-historical activity theory. Turkish Online Journal of Educational Technology, v. 14, n. 2, p. 219-228, 2015.

PYLE, D.; PYLE, N.; LIGNUGARIS/KRAFT, B.; DURAN, L.; AKERS, J. Academic Effects of PeerMediated Interventions with English Language Learners: A Research Synthesis. Review of Educational Research, v. 87, n. 1, p. 103-133, 2016.

RICHARDS, J. C. The Changing Face of Language Learning: Learning Beyond the Classroom. RELC Journal, v. 46, n. 1, p. 5-22, 2015.

ROCHA, C. H. Propostas para inglês no ensino fundamental I público: plurilinguismo, transculturalidade e multiletramentos. 2010. Tese (Doutorado) - Universidade Estadual de Campinas, Instituto de Estudos da Linguagem, Campinas, 2010.

SALAS, A. Literature review of faculty-perceived usefulness of instructional technology in classroom dynamics. Contemporary Educational Technology, Eskisehir, v. 7, n. 2, p. 174186, 2016.

SALOMÃO, A. C. B. A formação do formador de professores: perspectivas de colaboração entre graduandos e pós-graduandos no projeto Teletandem Brasil. Revista Brasileira de Linguística Aplicada, São Paulo, v. 11, n. 3, p. 653-677, 2011.

SALOMÃO, A. C. B. A. Teletandem and telepresence: Rethinking the cultural component in language teaching and language teacher education. DELTA: Documentação de Estudos em Linguística Teórica e Aplicada, São Paulo, v. 31, n. 3, p. 781-800, 2015.

TELLES, J. A.; VASSALLO, M. L. Foreign language learning in-tandem: Teletandem as an alternative proposal in CALLT 1. The ESPecialist, São Paulo, v. 27, n. 2, p. 1-32, 2006.

TIRABOSCHI, F. F. Prática de multiletramentos e Teletandem: uma experiência com aprendizes de língua inglesa da educação básica. Revista Forproll, Goiânia, v. 1, n. 2, p. 105-118, 2017. 
- | Experiencing teletandem: a collaborative project to encourage students' in tandem interactions

TOlOSA, C.; ORDÓÑEZ. C. L.; GUEVARA, D. C. Language Learning Shifts and Attitudes Towards Language Learning in an Online Tandem Program for Beginner Writers. PROFILE, v. 19, n. 1, p. 105-118, 2017. Available in: https://files.eric.ed.gov/fulltext/EJ1125676.pdf. Access: Nov. 282018.

VYGOTSKY, L. S. A formação social da mente: o desenvolvimento dos processos psicológicos superiores. São Paulo: Martins Fontes, 1998.

VYGOTSKY, L. S. Mind in society: The development of higher psychological processes. Harvard: Harvard University Press, 1980.

VYGOTSKY, L. S. Thought and Language. Ontario, Canada: Massachusetts Institute of Technology Press, 1962.

WARSCHAUER, Mark. Computer-Mediated Collaborative Learning: Theory and Practice. The Modern Language Journal, v. 81, n. 4, p. 470-481, 1977. Available in: http://education. uci.edu/uploads/7/2/7/6/72769947/cmcl.pdf. Access: Nov. 282018.

COMO CITAR ESTE ARTIGO: KLEN-ALVES, Viviane; TIRABOSCHI, Fernanda Franco. Experiencing Teletandem: A collaborative project to encourage students in tandem interactions. Revista do GEL, v. 15, n. 3, p. 109-130, 2018. Disponível em: https://revistadogel.gel.org.br/

DOI: http://dx.doi.org/10.21165/gel.v15i3.2416

Submetido em: 18/11/2018 | Aceito em: 17/12/2018. 